\title{
UJI BIOAKTIVITAS EKSTRAK BUAH SAWO MANILA (Manilkara zapota) TERHADAP PERTUMBUHAN BAKTERI Salmonella typhi
}

\author{
${ }^{1}$ Subakir Salnus \\ ${ }^{2}$ Nurhamsia
}

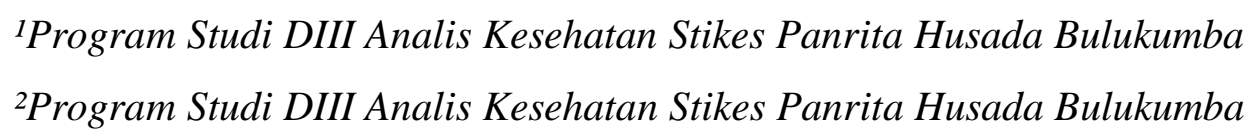

\section{Alamat Koresponden:}

Program Studi DIII Analis Kesehatan

Sekolah Tinggi Ilmu Kesehatan Panrita Husada

Bulukumba, 04132514721

Hp. 082393644353

Email: akil.ladzinrank@gmail.com 


\begin{abstract}
ABSTRAK
Penelitian ini dilakukan uji bioaktivitas menggunakan buah sawo manila (Manilkara zapota) sebagai media hambat pertumbuhan bakteri Salmonella typhi penyebab penyakit tipes/tifus. Bakteri Salmonella typhi merupakan salah satu spesies bakteri yang berbentuk basil, gram negatif, fakultatif aerob, bergerak dengan flagel pertrich. Buah sawo manila muda mempunyai aktivitas antimikroba terhadap Salmonella typhi, karena mengandung berbagai senyawa metabolit sekunder diantaranya adalah saponin, tanin dan flavonoid. Tujuan penelitian ini untuk mengetahui seberapa besar uji daya hambat buah sawo manila (Manilkara zapota) terhadap pertumbuhan Salmonella typhi. Penelitian ini merupakan ekperimen laboratorik menggunakan metode diffusion test (sumuran). Sampel penelitian ini adalah ekstrak buah sawo manila muda (Manilkara zapota). Pada ekstrak sawo manila konsentrasi 35\% tidak dapat terbentuk zona daya hambat (0 mm), konsentrasi $40 \%$ terdapat zona daya hambat $(9 \mathrm{~mm})$, konsentrasi $45 \%$ terdapat zona daya hambat $(13 \mathrm{~mm})$, konsentrasi $50 \%$ terdapat zona daya hambat $(13,5 \mathrm{~mm})$, dan konsentrasi zona daya hambat $55 \%$ terdapat zona daya hambat (18 mm). Dengan hasil ini dapat dikatakan bahwa ekstrak buah sawo manila dapat menghambat pertumbuhan bakteri Salmonella typhi, maka selanjutnya dapat dilakukan penyuluhan kepada masyarakat penderita penyakit tipes/tifus untuk mengunsumsi buah sawo manila sehingga dapat mengurangi pertumbuhan bakteri tersebut.
\end{abstract}

Kata Kunci: Bioaktivitas, Salmonella Typhi, Sawo Manila

\begin{abstract}
This research was conducted bioactivities by using raw fruits of sapodilla sapota (Manilkara zapota) as a drag growth media of Salmonella typhi bacteria causes typhoid fever disease. Salmonella typhi is a species of bacteria that are gram-negative bacilli shaped, facultative, aerobic, moving with a single pertrich. Sapdilla sapota has antimicrobial activity against Salmonella typhi, because it contains a variety of secondary metabolite compounds such as saponins, tannins and flavonoids. The purpose of this research was to know how efective the raw fruits of sapodilla sapota (Manilkara zapota) against the growth of Salmonella typhi. This is an laboratory research by using diffusion test method. The sample of this research is to extract the fruit of sapodilla sapota (Manilkara zapota) crude. The results of this research, are 35\% concentration of extract cannot be formed drag zone $(0 \mathrm{~mm})$, but in $40,45,50$ and $55 \%$ of concentration there are had drag zone $(9 \mathrm{~mm}, 13 \mathrm{~mm}, 13.5 \mathrm{~mm}$, and $18 \mathrm{~mm}$ ). this can be said that the raw fruit of sapodilla sapota extract can inhibit the growth of Salmonella typhi bacteria can be done, then the next extension to the sufferers of the disease typhus to consume raw fruits of sapodilla sapota so that can reduce the growth of bacteria.
\end{abstract}

Keywords - Bioactivities, Salmonella Typhi, Sapodilla Sapota 


\section{PENDAHULUAN}

Masyarakat Indonesia kaya akan sumber bahan alami dan obat tradisional yang telah digunakan oleh sebagian besar masyarakat secara turun temurun. Sebelum obat-obat kimia berkembang secara modern, nenek moyang kita umumnya menggunakan obat-obatan yang berasal dari buah-buahan atau tanaman untuk mengatasi masalah kesehatannya karena dipercaya mempunyai kelebihan yaitu memiliki efek samping yang kecil dibandingkan dengan pengobatan kimiawi (Angriani, 2012). salah satu buah yang memiliki potensial digunakan sebagai obat adalah sawo manila.

Tumbuhan sawo manila mengandung senyawa-senyawa metabolit sekunder seperti flavonoid, saponin dan tanin. Ketiga senyawa tersebut memiliki sifat antibakteri. Buah sawo yang masih muda rasanya pahit dan kelat disebabkan tingginya kandungan tanin, sehingga daya antibakteri buah sawo yang masih muda lebih tinggi jika dibandingkan dengan buah sawo yang sudah matang. Secara etnobotani dan hasil kajian beberapa literatur, buah ini dapat digunakan sebagai obat penyakit typhus yang dapat menyebabkan demam typhoid. Masyarakat menggunakan buah ini dalam bentuk perasan (jus) untuk di minum. Di Indonesia, demam typhoid (Typhus) adalah penyakit bakteri yang menyebabkan kematian sekitar 3 juta penduduk setiap tahun dari beberapa provinsi seperti Jakarta, Pontianak, Makassar, Batam, dan lainlain (Mustari, 2011).

Manfaat buah sawo sebelumnya telah diteliti oleh para peneliti Fakultas Farmasi di Universitas Hasanuddin tentang uji daya hambat dan analisis bioautografi perasan buah sawo manila (Manilkara zapota) terhadap bakteri uji Salmonella typosa dengan hasil yang di peroleh menunjukkan bahwa sawo manila (Manilkara zapota) mampu menghambat pertumbuhan bakteri uji Salmonella typhi dengan diameter hambatan terbesar $18,68 \mathrm{~mm}$ pada konsentrasi
45\% menggunakan sampel perasan buah sawo manila yang matang. Hasil ini dapat di jadikan acuan bahwa buah sawo manila dapat menghambat pertumbuhan bakteri Salmonella typhosa karena adanya kandungan senyawa metabolit sekunder seperti saponin, tanin dan flavonoid.

\section{METODE}

\section{A. Metode}

Jenis penelitian ini adalah eksperimen secara laboratorik untuk mengetahui berapa besar uji daya hambat ekstrak buah sawo manila (Manilkara zapota) terhadap pertumbuhan bakteri Salmonella typhi. Metode pemeriksaan dalam penelitian ini adalah Diffusion Test (sumuran) menggunakan media Muller Hilton Agar (MHA). Penelitian telah dilaksanakan di laboratorium Mikrobiologi Klinik GG Makassar pada tanggal 12 hingga 17 November 2018.

\section{B. Kerangka Operasional}

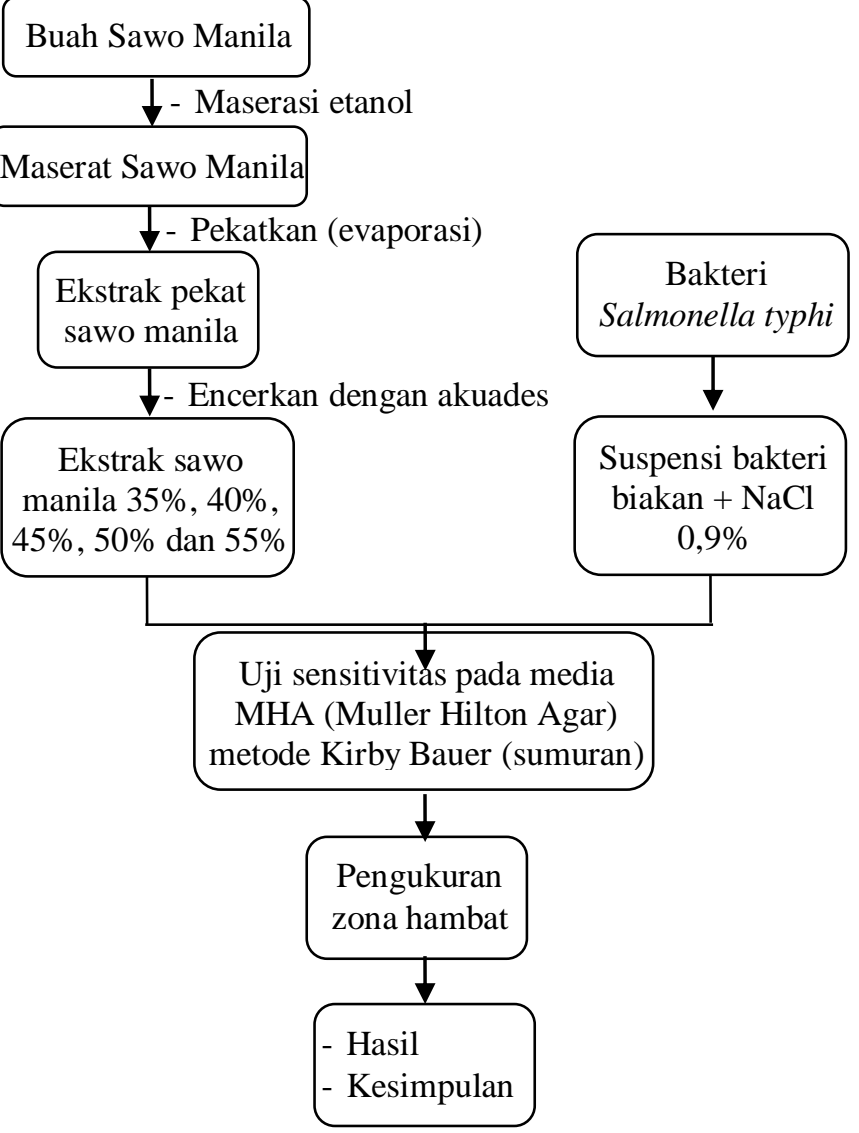




\section{HASIL DAN PEMBAHASAN}

Berdasarkan hasil penelitian yang telah dilakukan di laboratorium Mikrobiologi klinik GG kota Makassar yang dimulai pada tanggal 12 hingga 17 November 2018 terhadap ekstrak buah sawo manila muda (Manilkara zapota) pada uji bioaktivitas untuk mengetahui daya hambat terhadap pertumbuhan bakteri Salmonella typhi dengan 5 perlakuan yaitu konsentrasi 35\%, 40\%, 45\%, 50\%, dan 55\% di peroleh hasil seperti yang ditunjukkan pada gambar 3.1 di bawah ini :

Berdasarkan gambar 3.1 dapat ditentukan konsentrasi ekstrak buah sawo manila terbesar memiliki dampak diameter zona hambat terhadap pertumbuhan bakteri Salmonella typhi yaitu pada konsentrasi $55 \%$.

Standar diameter zona hambat antibiotik Chloramfenikol $30 \quad \mu \mathrm{g}$ terhadap bakteri Salmonella typhi dengan diameter zona hambat $<12 \mathrm{~mm}$ memiliki respon daya hambat yang bersifat resisten $(\mathrm{R})$, pada diameter zona hambat 13-17 mm memiliki respon daya hambat yang bersifat intermediate (I), dan pada diameter zona hambat $>18 \mathrm{~mm}$ memiliki respon daya hambat yang bersifat sensitif $(\mathrm{S})$.

Adapun hasil uji daya hambat dari ekstrak buah sawo manila (Manilkara zapota) terhadap pertumbuhan bakteri Salmonella typhi ditunjukkan pada tabel 3.1 dibawah ini :

Pada tabel 3.1 hasil pengamatan zona hambat yang terbentuk pada uji daya hambat buah sawo manila muda (Manilkara zapota) terhadap pertumbuhan bakteri Salmonella typhi setelah masa inkubasi selama 24 jam pada suhu $37^{\circ} \mathrm{C}$ menunjukkan bahwa ekstrak sawo manila muda pada konsentrasi $35 \%$ tidak terbentuk zona daya hambat $(0 \mathrm{~mm})$, konsentrasi $40 \%$ terdapat zona daya hambat $(9 \mathrm{~mm})$, konsentrasi $45 \%$ terdapat zona daya hambat $(13 \mathrm{~mm})$, konsentrasi $50 \%$ terdapat zona daya hambat $(13,5 \mathrm{~mm})$, dan konsentrasi $55 \%$ terdapat zona daya hambat (18 $\mathrm{mm})$.

Hasil uji daya hambat perasan buah sawo manila muda untuk masing-masing konsentrasi memiliki diameter zona hambat yang terbentuk berbeda-beda. Konsentrasi $55 \%$ memiliki pembentukan zona hambat yang sensitif (S) terhadap bakteri Salmonella typhi. Hal ini menunjukkan bahwa semakin besar konsentrasi maka akan semakin besar pula kandungan aktivitas antimikroba yang bersifat antibakteri. Pembentukan zona hambat pada konsentrasi $35 \%$ tidak memiliki respon daya hambat, terhadap bakteri Salmonella typhi. Hal ini menunjukkan bahwa pada konsentrasi yang rendah, aktivitas senyawa antimikroba yang bersifat antibakteri yang terkandung dalam buah sawo manila muda tidak cukup untuk menghambat pertumbuhan bakteri Salmonella typhi.

\section{Kesimpulan}

Kesimpulan dari hasil penelitian ini yaitu :

1. Ekstrak buah sawo manila muda (Manilkara zapota) terbukti dapat menghambat pertumbuhan bakteri Salmonella typhi

2. Semakin tinggi konsentrasi ekstrak buah sawo manila maka zona daya hambat akan semakin besar.

\section{DAFTAR PUSTAKA}

[1] Bakhri, S Dkk. 2015. Penuntun Praktikum Bakteriologi II. Kemenkes: Makassar.

[2] Indah, 2003. Mikrobiologi dan Parasitologi untuk Akademi Keperawatan dan Sekolah Tenaga Kesehatan yang Sederajat. PT Citra Aditya Bhaty: Bandung.

[3] Ahmad, K.A. 2003. Kamus Lengkap Kedokteran Gitamedia Press: Surabaya.

[4] Leonardus, dkk. 2016. Penuntun dan Jurnal Praktikum Bakteriologi III. Kemenkes: Makassar.

[5] Hasyimi, M. 2010. Mikrobiologi Parasitologi Untuk Mahasiswa Keperawatan. CV.Trans Info Media: Jakarta. 
[6] Rasni, 2008. Batas Maksimum dalam Pangan Bogor Cemasan Mikroba.: Bogor

[7] Saputra, Lyndon. 2011. Buku Ajar Mikrobiologi Kedokteran. Binarupa Aksara: Tanggerang.

[8] Syariefa, Evy. 2012. Buah Unit, Cara Buahkan dan Rawat. PT Trubus Swadaya: Jakarta.

[9] Tambayong, Jan. 2000. Mikrobiologi untuk Keperawatan. Widya Medika: Jakarta.

[10] Astarina, W. 2010. Kamus Keperawatan Lengkap. Serba Jaya: Surabaya. 
Gambar 3.1 Hasil Uji bioaktivitas ekstrak sawomanila terhadap bakteri Salmonella typhi pada konsentrasi 35\%, 40\%, 45\%, 50\%, 55\% dan kontrol positif-negatif

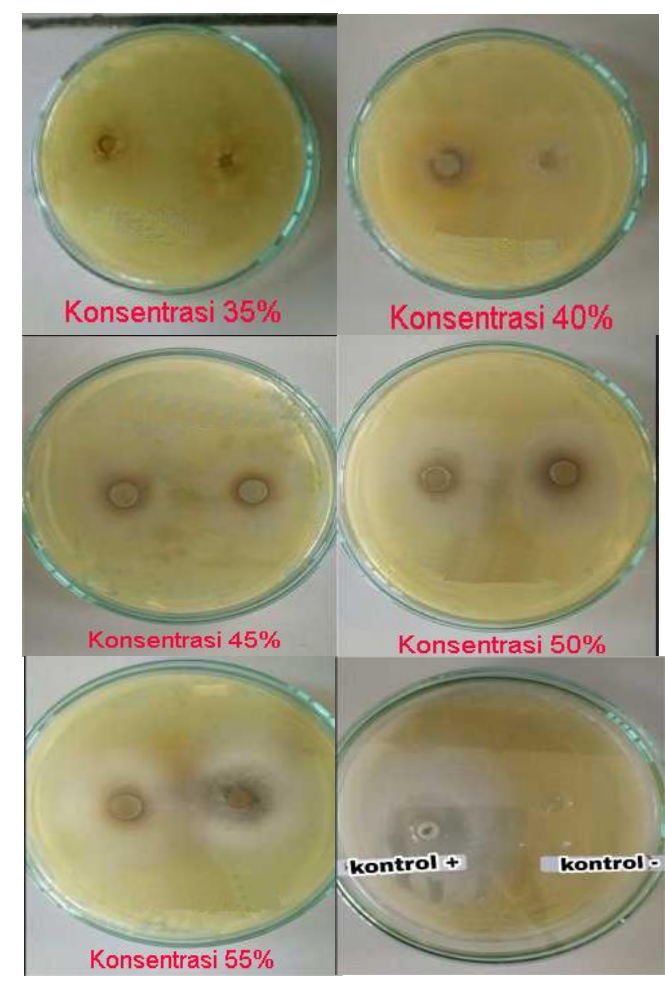

Tabel 3.1 Hasil uji daya hambat ekstrak buah sawo manila (Manilkara zapota) terhadap pertumbuhan bakteri Salmonella typhi.

\begin{tabular}{|c|c|c|}
\hline No & Konsentrasi (\%) & $\begin{array}{c}\text { Diameter zona daya } \\
\text { hambat }(\mathbf{m m})\end{array}$ \\
\hline 1. & 35 & 0 \\
\hline 2. & 40 & 9 \\
\hline 3. & 45 & 13 \\
\hline 4. & 50 & 18,5 \\
\hline 5. & 55 & 0 \\
\hline 6. & $\begin{array}{l}\text { Kontrol Negatif } \\
\text { (Akuades Steril) }\end{array}$ & 25 \\
\hline 7. & $\begin{array}{l}\text { Kontrol Positif } \\
\text { (Chloramfenikol) }\end{array}$ & \\
\hline
\end{tabular}

